\title{
CAUGHT IN A CROSSFIRE: CAMPAIGN SPEECHES OF PRESIDENT RODRIGO ROA DUTERTE (PRRD)
}

\author{
Danna Karyl Jane C. Talde \\ Faculty, Department of Languages and Literature, Central Mindanao University, Maramag, Bukidnon, \\ Philippines
}

Article DOI: https://doi.org/10.36713/epra8585

DOI No: 10.36713/epra8585

\begin{abstract}
Through the use of critical discourse analysis, this study aimed to analyze PRRD's campaign speeches with the purpose of establishing its discursive patterns. The study employed the descriptive-qualitative design which utilized Critical Discourse Analysis, anchored with Systemic Functional Linguistics (SFL) by Halliday. Results show the highest frequency of the following lexico-grammatical features: modals will, would, should, and shall; pronoun I (me); and verb tense present simple. Results also reveal that verbal process constitutes the highest in terms of transitivity, while it is positive median politeness for modality. Also, the analysis reveals that the informative, regulatory, and instrumental are the dominant functions of language used by PRRD. Based on the findings, PRRD stressed his campaign speeches with willingness, determination, certainty, and fortitude, with greater involvement of himself; PRRD had gone extra-mile to attack the personalities of the other parties for self-projection and selfpromotion, along with the expression of enthusiasm, optimism, and determination to elicit support from the populace; and PRRD focused on neutralizing the asymmetrical power relations that existed between him and the electorate, but with the emphasis of control, and needs of his countrymen.
\end{abstract}

KEYWORDS - Critical Discourse Analysis, Campaign Speeches, Language Functions, Discourse Features, Transitivity, Modality

\section{INTRODUCTION Rationale}

Since Duterte's official declaration to run for presidency in the Philippines, his name has never been dormant from online and print news articles, TV reports, and even in social media comments and threads, may it be negative or positive. With this, it only suggests that his iron fist and his strong personality have captured most Filipinos, if not all. In fact, when he spoke during his campaign sorties, listeners were laughing, crying, thinking, and reflecting in spite of the criticisms from the supporters of his rivals. Nevertheless, his supporters still remain faithful to him that he sustained his lead since February 2016 pre-election polls. These examples just prove that more than his tough-talking and feisty ways, it is Duterte's sympathy to people's concerns that sets him apart from other political personalities.

However, there is this curiosity about how he talks, how he organizes his speeches, and how he expresses his thoughts in a form of discourse that he sounds emulating and talks captivating compared to the other Filipino political candidates.

Speeches are actually deemed unique varieties of spoken discourse which are due for investigation of grammatical aspects of language (van der Zee, 2013). This means that those who use this genre must know the application of appropriate linguistic features in the construction of ideas. It must also be exercised with command and control, tactics, and power as these 


\section{EPRA International Journal of Research and Development (IJRD)}

elements are crucial in bringing the speaker's identity and societal stand.

Only few studies are conducted on the context of political genre in the Philippines. These are the analysis of the State of the Nation Address (SONA) and Inaugural Speeches just like those of Marcos, Estrada, and Arroyo (Jibrin, 2003) and former President Benigno C. Aquino III (van der Zee, 2013) wherein both studies highlighted the overall structure of the linguistic units used, along with the styles and attitude of delivery. In other words, it is rare to find studies that use campaign speeches as the corpora anchored with Critical Discourse Analysis, especially from a beguiling leader - PRRD. Hence, the academic world needs a breakthrough of a study of another form of discourse (campaign speech) especially from an enticing personality in order to compliment the studies about the previous Philippine presidents' SONA and Inaugural speeches.

In this regard, there is a need to establish the discursive strategies and practices of PRRD in terms of language functions. This is important to reveal the power relations and discriminations happening in the society which could be attained through the utilization of critical discourse analysis. This is attained through investigating the discourse features and speech structure of PRRD's campaign speeches.

\section{Objectives of the Study}

Generally, this study aimed to analyze the discursive patterns found in the campaign speeches of PRRD through critical discourse analysis.

Specifically, it aimed to identify the overall lexico-grammatical structure, determine the discourse features in terms of transitivity and modality, and identify the dominant functions of language manifested in PRRD's campaign speeches.

\section{METHODOLOGY}

This study is qualitative in nature that is designed to deal with the complexities of meaning in both social and political context, which are naturalistic (not controlled) and observational (not experimental).
Moreover, in order to identify the structure and discourse features of the selected campaign speeches, the researcher made use of the research instruments utilized by Wang (2010). These research instruments served as guidelines to come up with reliable results of the study. Although the identification of the ideational function (transitivity) and the interpersonal functions (modality) could be criticized for their subjectivity, the researcher dealt with the problem through the validation suggestion of Lincoln and Guba as used by van der Zee (2013).

Furthermore, the corpora of the study were sourced from the five (5) selected campaign speeches of PRRD downloaded from Youtube. After all the corpora were gathered through purposive sampling method, in-depth analysis followed through the use of Halliday's Systemic Functional Linguistics. The research made use of a top-down approach in examining the lexico-grammatical features (modal verbs, verb tenses, and pronouns), the discourse features (mental, relational, behavioral, material, verbal, and existential), modality (levels of politeness), and the language functions.

Then, three debriefers were asked to check the validity of the results, except for the analysis of the dominant functions of language which was inter- to ensure not just validity but also reliability in the attainment of the main purpose of the study. The validators were identified based on their relatedness, knowledge, and expertise in the field of English. To guide them in their review of the analysis, the researcher utilized the proposed four (4) criteria of Lincoln and Guba (Wang, 2010), such as confirmability, credibility, transferability, and dependability.

\section{RESULTS AND DISCUSSION Overall Lexico-grammatical Structure}

One of the concerns of the study is the overall lexico-grammatical structure of PRRD's campaign speeches which covers the use of modal verbs, personal pronouns, and tenses. 


\section{EPRA International Journal of Research and Development (IJRD)}

Table 1. Overall Lexico-grammatical Structure

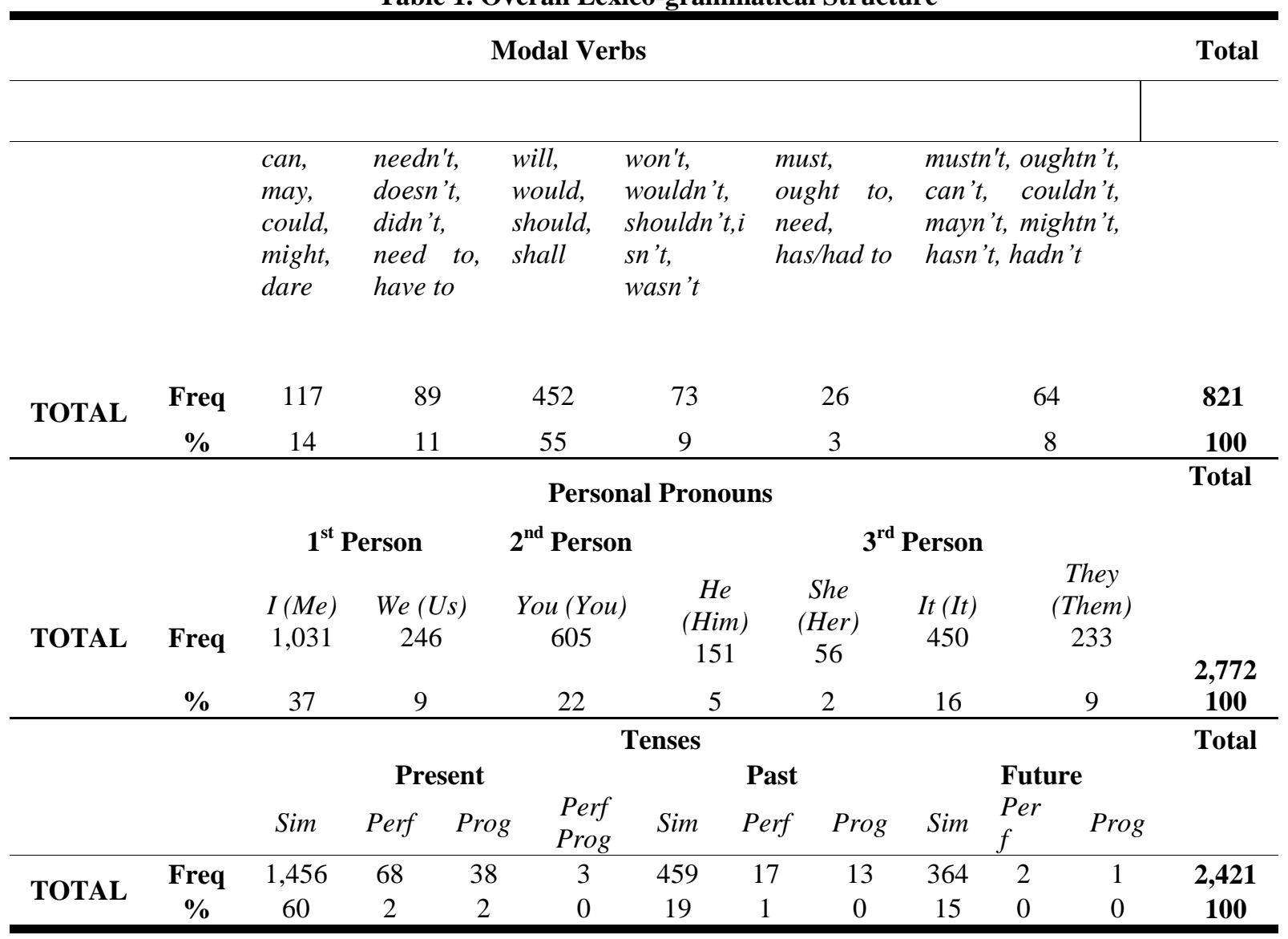

Table 1 presents that the group of modal verbs such as will, would, should, and shall is the highest in frequency, followed by the modal verbs can, may, could, might, and dare. However, findings show that there is less usage on the modal verbs must, ought to, need, has/had to. This implies that PRRD was trying to convince his listeners by emphasizing and suggesting more concrete conveyance of his firm will to fix government and rule the nation proficiently (using will, would, should, and shall). Then, he supported it with an appeal by stating his capabilities, knowledge, skills, and strong determination to transform the Philippines into a better nation (using can, may, could, might, and dare). However, he was trying to put forth more responsibility to himself rather than placing it on the Filipinos masses since he rarely used the modals must, ought to, need, and has/had to which imply the participation of others as also supported by the result of personal pronouns. With all these dominant modals used, it could be said that PRRD was able to express positive concern for others through a non-imposing distancing behavior.

\section{Discourse Features in Terms of Transitivity and Modality}

a. On Transitivity

Having the verbal process as the highest, followed by mental, relational, and relational processes, means that political language is a mass mobilizing text (Al-Faki, 2014) and it reveals that he is a man who could play with words. In other words, PRRD could employ linguistic choices converging that of the situation. His frequent use of verbal processes shows the objectivity and reality embedded behind those words, while the mental processes ascertain his agony, dismay, and anxiety towards the Filipino people and their coming generations. Eventually, he was able to magnify his points by using relational and behavioral processes. This means that there are various factors that help 


\title{
SJIF Impact Factor 2021: 8.013| ISI I.F.Value:1.241| Journal DOI: 10.36713/epra2016 \\ ISSN: 2455-7838(Online) \\ EPRA International Journal of Research and Development (IJRD)
}

\author{
Volume: 6 | Issue: 9 | September $2021 \quad$ - Peer Reviewed Journal
}

codify messages in the realm of discourse when developing ideological presuppositions which lie behind the surface structures of language indicated by repetitions and patterns.

\section{b. On Modality}

Meanwhile, the discourse features in terms of modality show that median positive level (will, would, should, and shall) is the most frequent, followed by low positive, low negative, median negative, high negative, and lastly, high positive.

These findings show that PRRD was reaching out for the favor of the electorate. There were also observations of including himself to the thought that he also feels and experiences the problems, sacrifices, and struggles of the Filipino masses. Similarly, this study is in congruence to the study of van der Zee (2013) in which she also found out great manifestation of the positive median politeness from the speeches of a politician. Having this result suggests that PRRD is determined enough to fulfill his promises with the thought in mind seeking for cooperation as well as establishing belongingness with his listeners.

Furthermore, PRRD was noticed to have used more positive politeness as compared to negative politeness. Although it is said that the negative politeness is more ideal because of its non-imposing, contrite manner (Ogiermann, 2009), PRRD's style is the opposite as he sought for the positive face needs of his listeners, hence, developing positive face. According to Yabuuchi (2006), positive politeness strategies emphasize rapport, and through this, the speaker's goal become comparable to the hearers. This means that PRRD did not want to go far from his hearers, but he made a clear connection and understanding between them as he verbalized his thoughts, which led the hearers to feel comfortable with him. According to Watts et al. (2008), the speaker of this kind could accomplish familiarity and claim common ground by attending to the hearer's wants, interests, needs, or goods, exaggerating his interests, approval, or sympathy, and demonstrating an intensified interest to the hearer. Thus, PRRD, frank he may have sounded, still was able to project his own style of connection to his audience.

However, positive polite modals were not quite evident in his campaign speeches. This outcome conforms to the study of Pilegaard (1997) which articulates that the distribution, form, and level of positive and negative politeness in an utterance has a connection to the status of the speaker. It was also added that there are variations according to the dynamics of the course of communication. In other words, PRRD used those words not just for the sake of communicating, but for the purpose of efficiently evoking his stand, perceptions, and judgments on what was going on in the government system.

\section{Dominant Functions of Language}

Out of the seven functions of language, the informative function obtained the highest frequency, followed by regulatory, and instrumental. With this, it can be deduced that PRRD's discursive pattern highlights the giving of information, anchored with the giving of orders and instructions to control his fellowmen, which he justified through stressing the needs and desires of the country, for the country. Moreover, it implies that a message could be captivating when a large amount of information is shared, supported with the expression of control and demand which would emulate listeners to be good and accountable citizens. Also, in delivering a campaign speech, one should not forget to state the necessities and longings of the country because like the Philippines, its people are thirsty and hungry for comfortable living and effective governance.

Having the highest manifestation of the informative function in PRRD's campaign speeches derived from the linguistic and discourse features gathered in the first two (2) problems, it could be deduced that his way of persuasion dwelt mostly on presenting facts, tackling about the real world, and expressing a proposition to convey the message. In fact, this result coincides with the extensive use of verbal processes in the campaign speeches as presented in the previous discussion. This suggests that PRRD wanted to emphasize the bearing of truth and value in his speeches which was revealed through disclosing failures of the previous administration and stressing their corruptible manners during their service in the government. In other words, PRRD utilized informative language to deface the other parties.

With this tactic, the listeners may be convinced not to vote for the other presidential candidates because plenty of intriguing information was shared with them. Also, the use of informative function could be effective for it can also take the form of a command or directive. In fact, one cannot persuade without any information given.

The outcome of the study is actually supported by the central assumption of CDA and SFL where speakers make choices regarding the choice of word 


\section{SJIF Impact Factor 2021: 8.013| ISI I.F.Value:1.241| Journal DOI: 10.36713/epra2016 \\ ISSN: 2455-7838(Online) \\ EPRA International Journal of Research and Development (IJRD)}

Volume: 6 | Issue: 9 | September 2021

- Peer Reviewed Journal

and sentence construction which are principled and systematic either intentionally or not. In other words, PRRD's choices of words are produced based on his ideologies which are formed by his environment. Based on his biography, he is a lawyer who had also been a prosecutor in Davao City for years. This background may support his extensive use of an informative function which does not only transmit mere information but also mixed with suggestions that listeners need to weigh rationally as it concerns the future of the Philippines.

Moreover, the results are supported by the method of Wodak and Ludwig (1999) in their method to CDA and SFL, wherein it is stated that discourse always involves power and ideologies, and is always historical. In other words, power in a campaign speech may be formed with other communicative events which are happening, or already have happened. This means that there is an integration of historical knowledge concerning social and political fields through which discursive events are manifested. The same is also true to the study of Kamalu and Agangan (2011) where it was also found that a campaigning candidate uses variety of discursive strategies like the use of an appeal or influence.

\section{CONCLUSION}

Based on the findings, the study concludes that PRRD stressed his campaign speeches with all willingness, determination, certainty, and fortitude, along with greater involvement of himself to truly achieve his promises.

Moreover, the study concludes that PRRD had gone extra mile to attack the personalities of the other parties for self-projection and self-promotion, along with the expression of enthusiasm, optimism, and determination, to elicit support from the populace.

In addition, the study concludes that PRRD focused on neutralizing the asymmetrical power relations that existed between him and the electorate, but with an emphasis of control, and needs of his countrymen.

\section{Recommendations}

In light of the findings and conclusions of the study, several recommendations are offered for the furtherance of the research.

Other lexico-grammatical features may be considered in order to establish a wide range of scope to fully understand the discourse features of PRRD's campaign speeches. Also, a comparative study among the campaign speeches of the presidential candidates may be done in order to differentiate their style of discourse. Moreover, one of the members of PRRD's secretariat with knowledge in English Grammar may be considered as one of the debriefers in order to gather much reliable results. Likewise, other speeches delivered by PRRD (i.e. Inaugural speech, SONA) may also be studied in order to verify his discourse styles and features. In addition, an in-depth study may be done to identify the effectiveness of the choice of words in relation to the establishment of power in speeches.

\section{REFERENCES}

1. Al-Faki, I. M. (2014). Political speeches of some African leaders from linguistic perspective (19812013). International Journal of Humanities and Social Science, 4(3), 180-198. http://www.ijhssnet.com/ view.php? u=http://www.ijhssnet.com/journals/Vol_ 4_No_3_February_2014/18.pdf

2. Fairclough, N. L. (1995). Critical discourse analysis: The critical study language. Harlow, UK: Longman.

3. Halliday, M.A.K. (2002). On grammar: Volume 1 of the collected works of Michael Halliday. London: Continuum.

4. Jibrin, C. (2003). A political discourse analysis of the state-of-the-nation addresses of five Philippine presidents. Published Dissertation. De La Salle University, Philippines.

5. Kamalu, I. \& Agangan, R. (2011). A critical discourse analysis of Goodluck Jonathan's declaration of interest in the PDP presidential primaries. Language, Discourse and Society, 1(1), 32-54.

6. Newmark, P. (1993). Paragraphs on translation. Clevedon, Philadelphia, Adelaide: Multilingual Matters. Canadian Modern Language Review, 53(4), 752-753.

7. Ogiermann, E. (2009). Politeness and In-directness across Cultures: A Comparison of English, German, Polish and Russian Requests. Journal of Politeness Research, 5 (2), 189-216.

8. Pilegaard, M. (2015). Politeness in written business discourse: A textlinguistic perspective on requests. https://www.researchgate.net/ publication/40235564_Politeness_in_written_busin ess_discourse_A_textlinguistic_perspective_on_req uests

9. van der Zee, T. (2013). Critical discourse analysis of the speeches of President Benigno $S$. 
Aquino (Unpublished Master's Thesis). University of South-Eastern Philippines, Davao City, Philippines.

10. Wang, J. (2010). A critical discourse analysis of Barack Obama's speeches. Journal of Language Teaching and Research, 1(3), 254-261. doi:10.4304/jltr.1.3.254-261

11. Watts, R., Ide, S. \& Ehlich, K. (2008). Politeness in Language: Studies in its History, Theory and Practice. Berlin, New York: De Gruyter Mouton. https://doi.org/10.1515/9783110199819

12. Wodak, R., \& Ludwig, C. (1999). Challenges in a changing world : issues in critical discourse analysis.

https://books.google.com.ph/books/about/Challenge s_in_a_Changing_World.html?id=u$m N Q g A A C A A J \&$ redir_esc $=y$

13. Yabuuchi, A. (2006). Hierarchy politeness: What Brown and Levinson refused to see. Intellectual Pragmatics, 3 (3), 323-351. 